\title{
Perforacja lewej komory serca u chorej z blokiem przedsionkowo-komorowym - opis przypadku
}

\section{Left ventricular perforation in patient with atrioventricular block - case study}

\author{
Anita Suwała ${ }^{1}$, Jerzy Sieńko ${ }^{2}$, Mirosław Brykczyński ${ }^{3}$, Jan Pawlus $^{1}$, Tadeusz Sulikowski $^{1}$ \\ ${ }^{1}$ Klinika Chirurgii Ogólnej, Małoinwazyjnej i Gastroenterologicznej Wydziału Lekarskiego \\ Pomorskiego Uniwersytetu Medycznego w Szczecinie \\ ${ }^{2}$ Klinika Chirurgii Ogólnej i Transplantacyjnej Wydziału Lekarskiego Pomorskiego Uniwersytetu Medycznego w Szczecinie \\ ${ }^{3}$ Klinika Kardiochirurgii Wydziału Lekarsko-Dentystycznego Pomorskiego Uniwersytetu Medycznego w Szczecinie
}

\section{Streszczenie}

Perforacja komory serca jest rzadkim (dotyczy ok. 1\% chorych), ale bardzo poważnym powikłaniem, które może wystąpić po wszczepieniu układu kardiostymulującego. Zaprezentowano opis powikłań będących następstwem wszczepienia kardiostymulatora VVI oraz jego wymiany na elektrodę endokawitarną u 81-letniej chorej z blokiem przedsionkowo-komorowym II stopnia.

Słowa kluczowe: perforacja komory, jatrogenna tamponada, blok AV

Folia Cardiologica 2017; 12, 4: 408-410

\section{Wstęp}

Częstość występowania komplikacji związanych z wszczepieniem stymulatorów serca w ostatnich latach wzrasta. Prawdopodobnie wiąże się to z coraz większą liczbą implantacji złożonych układów stymulujących serce oraz z wiekiem chorych kwalifikowanych do tej procedury, nierzadko obciążonych dużą liczbą schorzeń współtowarzyszących [1, 2]. Powikłania związane z wszczepieniem elektrostymulacji można podzielić na wczesne (do 3 mies. po zabiegu) oraz późne [3].

Do powikłań można zaliczyć infekcje (w miejscu wszczepienia stymulatora [kieszonka], infekcyjne zapalenie wsierdzia), krwiak w kieszeni stymulatora, stymulacje mięśni ściany klatki piersiowej, przepony, drażnienie nerwu przeponowego, zakrzepicę żyły podobojczykowej lub jej bocznic oraz rzadziej występujące powikłania, niestety często związane z dużym ryzykiem zgonu - perforację pra- wego przedsionka lub prawej komory serca z towarzyszącą tamponadą [4]. Uszkodzenie przegrody międzykomorowej i następnie przebicie elektrodą lewej komory serca jest bardzo rzadkim powikłaniem procedury kardiologicznej wymagającym pilnej interwencji chirurgicznej.

\section{Opis przypadku}

Pacjentka w wieku 81 lat (wskaźnik masy ciała [BMI, body mass index] 16,6 kg/m²), z blokiem przedsionkowo-komorowym II stopnia, nadciśnieniem tętniczym oraz po histerektomii z powodu mięśniaków macicy w wywiadzie, została przyjęta do kliniki chirurgii ogólnej i transplantacyjnej w trybie pilnym z powodu podejrzenia krwawienia do jamy brzusznej po interwencjach kardiologicznych.

U chorej z powodu bloku przedsionkowo-komorowego wszczepiono stymulator dwujamowy (VVI) z dostępu przez prawą żyłę podobojczykową. Po dobie obserwacji pacjentka

Adres do korespondencji: dr n. med. Anita Suwała, Klinika Chirurgii Ogólnej, Małoinwazyjnej i Gastroenterologicznej, Wydział Lekarski, Pomorski Uniwersytet Medyczny, ul. Unii Lubelskiej 1, 71-252 Szczecin, e-mail: nitus2@wp.pl 
zaczęła zgłaszać pogorszenie samopoczucia oraz uczucie „kołatania” serca. W badaniu elektrokardiograficznym (EKG) potwierdzono zaburzenia rytmu serca pod postacią częstoskurczu komorowego. Wykluczono niedokrwienie mięśnia sercowego; wysunięto podejrzenie przemieszczenia elektrod. Wykonano repozycję stymulatora. Po zabiegu u chorej wystąpiły nagła duszność, silny ból w klatce piersiowej oraz pogorszenie stanu ogólnego. W wykonanym badaniu ultrasonograficznym (USG) serca stwierdzono dużą ilość płynu w worku osierdziowym. Wykonano punkcję osierdzia i odbarczono tamponade. Po punkcji osierdzia u pacjentki pojawiły się dolegliwości bólowe w nadbrzuszu oraz krwiak w powłokach nadbrzusza i dolnej części klatki piersiowej. W badaniach laboratoryjnych zaobserwowano również znaczną anemizację. Chorej przetoczono $2 \mathrm{j}$. koncentratu krwinek czerwonych (kkcz) + 2 j. świeżo mrożonego osocza (FFP, fresh frozen plasma). Po konsultacji chirurgicznej, ze względu na nasilone dolegliwości bólowe w obrębie nadbrzusza, chorą zakwalifikowano do badania metodą tomografii komputerowej (CT, computed tomography) jamy brzusznej i klatki piersiowej. Podczas przygotowania chorej do transportu wystąpiły problemy ze stymulacją serca. Wówczas kardiolog podjął decyzję o usunięciu stymulatora i założeniu elektrody endokawitarnej w celu zabezpieczenia chorej na czas transportu i ewentualnego zabiegu operacyjnego. Chorą przekazano do kliniki chirurgii ogólnej i transplantacyjnej. Podczas badania CT rozpoznano krwawienie do jamy otrzewnowej i krwiak lewej opłucnej oraz postawiono podejrzenie krwiaka w śródpiersiu. W trybie pilnym chorą przewieziono na blok operacyjny.

Po przygotowaniu chorej wykonano laparotomię i torakotomię pośrodkową. W trakcie laparotomii rozpoznano krwawienie do jamy brzusznej i rozwarstwiający krwiak przepony po lewej stronie z jej pęknięciem. Po otwarciu klatki piersiowej stwierdzono dużą ilość krwi w lewej jamie opłucnej. Po otwarciu worka osierdziowego uwidoczniono wystającą z lewej komory serca na około $5 \mathrm{~cm}$ końcówkę elektrody endokawitarnej (ryc. 1). Elektrodę odcięto, a pozostałą część usunięto z serca. Perforację lewej komory zaopatrzono, naszywając łatę z opłucnej ściennej. Pozostawiono drenaż opłucnej. Ewakuowano krwiak z rozwarstwionej przepony, a pęknięcie zaopatrzono pojedynczymi szwami. Chorą w ciężkim stanie po zabiegu przekazano na oddział intensywnej terapii (OIT), gdzie zmarła w 3. dobie po zabiegu operacyjnym w wyniku niewydolności wielonarządowej.

\section{Omówienie}

Perforacja serca jest rzadkim, ale bardzo ciężkim powikłaniem, które może wystąpić u chorych po zabiegu wszczepienia układów stymulujących serce. Uszkodzenie może dotyczyć zarówno przedsionka, jak i komory serca oraz zatoki wieńcowej i dużych pni naczyniowych. Powikłania te można podzielić na ostre (występujące w pierwszych $24 \mathrm{~h}$

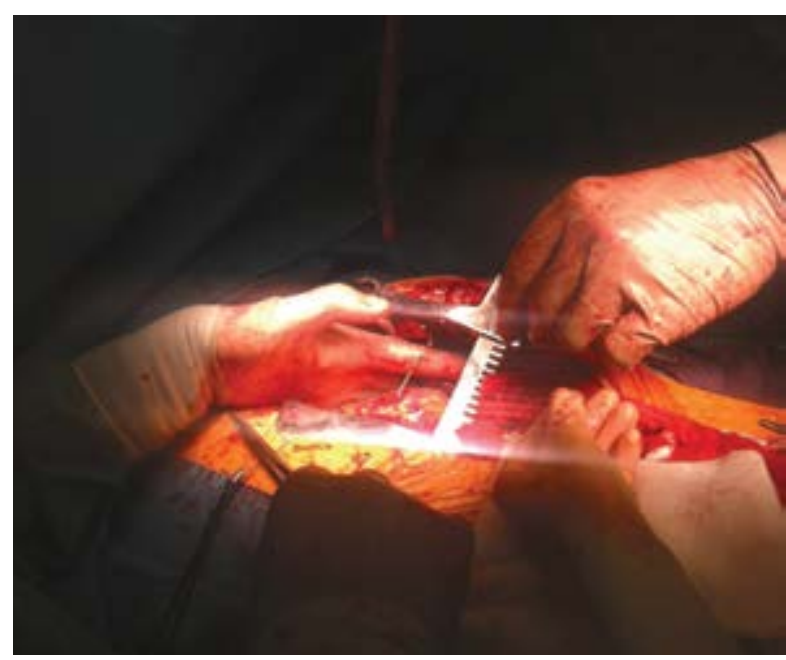

Rycina 1. Perforacja lewej komory serca - obraz śródoperacyjny

po implantacji i związane z występowaniem tamponady, a nawet zgonu chorego), podostre (występujące w ciągu miesiąca od zabiegu) i przewlekłe, występujące w odległym czasie. Inny podział obejmuje powikłania wczesne (w ciągu miesiąca) oraz późne perforacje. Do zwiększających ryzyko perforacji serca można zaliczyć następujące czynniki: zależne od samej stymulacji (konieczność ciągłej stymulacji, stymulację przedsionka), związane z wszczepionym urządzeniem (położenie w koniuszku serca), zależne od chorego - towarzysząca kardiomiopatia, płeć żeńska (szczególnie z niskim BMI $<20 \mathrm{~kg} / \mathrm{m}^{2}$ ), steroidoterapia lub stosowanie antykoagulantów w ciągu 7 dni przez wszczepieniem stymulatora czy urazy klatki piersiowej po implantacji [2-7].

Podostra lub przewlekła perforacja może przebiegać skąpoobjawowo, ostra często prowadzi do zgonu chorego. Chory najczęściej zgłasza nagły ból w klatce piersiowej, z towarzyszącym bólem w nadbrzuszu oraz trudnościami z oddychaniem. Można zaobserwować zaburzenia rytmu serca oraz objawy tamponady wywołane szybkim wypełnianiem się worka osierdziowego krwią, prowadzącą do zaburzeń kurczliwości mięśnia sercowego, zaburzeń rytmu serca, wstrząsu oraz zgonu.

Podstawami diagnostyki perforacji serca są badanie radiologiczne (RTG) klatki piersiowej, fluoroskopia oraz USG (przezklatkowej oraz przezprzełykowej). „Złotym standardem" w diagnostyce pozostaje CT [1, 2].

\section{Podsumowanie}

W omówionym przypadku pierwotnie doszło do perforacji prawego serca i wystąpienia tamponady po implantacji stymulatora VVI. Podczas odbarczenia krwi z worka osierdziowego wystąpiło powikłanie jatrogenne pod postacią uszkodzenia przepony z jej rozwarstwieniem wskutek krwiaka i następowego pęknięcia przepony i krwawienia 
do jamy brzusznej. Do uszkodzenia przegrody międzykomorowej i przebicia lewej komory serca doszło w następstwie wymiany stymulatora VVI na elektrodę endokawitarną.

\section{Konflikt interesów}

Autorzy nie zgłaszają konfliktu interesów.

\section{Abstract}

Heart perforation is rare but potentially fatal complication (about 1\% of patients) after pacemaker, cardioverter-defibrillator or electrostimulations electrodes implantations. Complications in 81-years-old women after pacemaker implantation, reimplantation and endocavity electrode implantation with second-degree atrioventricular block is presented.

Key words: ventricular perforation, iatrogenic tamponade, AV block

Folia Cardiologica 2017; 12, 4: 408-410

\section{Piśmiennictwo}

1. Piekarz J, Lelakowski J, Rydlewska A, et al. Heart perforation in patients with permanent cardiac pacing - pilot personal observations. Arch Med Sci. 2012; 8(1): 70-74, doi: 10.5114/aoms.2012.27284, indexed in Pubmed: 22457678.

2. Jacheć W, Tomasik A, Polewczyk A, et al. IST-3 Collaborative Group. [Complications following pacemaker implantation - presentation of two clinical cases]. Kardiol Pol. 2013; 71(7): 748-751, doi: 10.5603/ /KP.2013.0165, indexed in Pubmed: 23907911.

3. Małecka B, Kutarski A. Lead-dependent infective endocarditis: an old problem, a new name. Cardiol J. 2010; 17(2): 205-210, indexed in Pubmed: 20544626.

4. Byrd CL. Managing device-related complications and transvenous lead extraction. In: Clinical cardiac pacing, defibrillation, and resynchronization therapy. $3^{\text {rd }}$ ed. Ellenbogen KA, Kay GN, Lau CP, Wilkoff BL (eds). W.B. In: Ellenbogen KA, Kay GN, Lau CP, Wilkoff BL. ed. Clinical cardiac pacing, defibrillation, and resynchronization therapy. 3rd ed. W.B. Saunders and Elsevier Company, Philadelphia 2007: 855-966.

5. Laborderie J, Barandon L, Ploux S, et al. Management of subacute and delayed right ventricular perforation with a pacing or an implantable cardioverter-defibrillator lead. Am J Cardiol. 2008; 102(10): 1352-1355, doi: 10.1016/j.amjcard.2008.07.025, indexed in Pubmed: 18993154.

6. Haq SA, Heitner JF, Lee L, et al. Late presentation of a lead perforation as a complication of permanent pacemaker insertion. Angiology. 2008; 59(5): 619-621, doi: 10.1177/0003319707306438, indexed in Pubmed: 18388077.

7. Rydlewska A, Małecka B, Zabek A, et al. Delayed perforation of the right ventricle as a complication of permanent cardiac pacing - is following the guidelines always the right choice? Non-standard treatment - a case report and literature review. Kardiol Pol. 2010; 68(3): 357-361, indexed in Pubmed: 20411465. 